\title{
Seeing the Belly Dance as a Feminist Possibility: Gaze, Gender and Public Space in Istanbul
}

\author{
Işıl Eğrikavuk ${ }^{1}$ \\ Berlin University of Arts/UdK - Berlin, Germany \\ E-mail: isilegri@gmail.com
}

\section{Abstract}

This paper discusses the ancient form of belly dance as an example to speak more in depth about the public spaces of Istanbul, where the female body is constantly under surveillance by the male gaze. Over thousands of years, the ancient dance form of belly dance has been transformed from a collective women's ritual to a form of entertainment that serves the male gaze. This paper looks for the possibilities tore-define belly dance as a feminist counter strategy to revive its essence. Framed by the Muted Group Theory, this paper also exemplifies various artworks and strategies produced by female artists and analyze them in the light of this theory. It also searches for redefining the belly dance as part of a feminist identity and asks whether these artistic strategies could be pathways in re-defining belly dance as a feminist practice.

Feminism. Public Space. Belly Dance. Muted Group Gender.
Esse artigo discute a forma ancestral de dança do ventre como um exemplo para falar mais a fundo sobre os espaços públicos de Istambul, onde o corpo feminino está constantemente sob vigilância do olhar masculino. Em milhares de anos, a forma ancestral da dança do ventre foi se transformando de um ritual feminino coletivo para uma forma de entretenimento que atende ao olhar masculino. Esse artigo investiga possibilidades de redefinir a dança do ventre como uma contra estratégia feminista para reviver sua essência. Estruturado através da Teoria do Grupo Silenciado (Muted GroupTheory), esse artigo também exemplifica várias obras de arte e estratégias produzidas por mulheres artistas e analisa-os à luz dessa teoria. Além disso, busca refletir a dança do ventre a partir de uma identidade feminista e questiona se essas estratégias artísticas podem ser caminhos para redefinir a dança do ventre como uma prática feminista.

Feminismo. Espaço Público. Dança do Ventre. Teoria do Grupo Silenciado. Gênero. 


\section{Introduction}

In many places around the world, it is a battle for women to move in public spaces without being subject to the gaze of men. Yet, in a city in which gender equality is not taken for granted and in which public spaces tend to be dominated mostly by men, the problem becomes very urgent. The idea of this paper came from this urgency that I and most women in Turkey face every day and thinking of ways of subverting this situation.

My goal in this paper is to lay out the power dynamics created by gender hierarchies in public spaces, and show how women have been muted in public space through the gaze of men. Alternatively, I will also look for possibilities to challenge these gender relations through both a theoretical and an artistic approach that involves body and dance and finally ask whether this could become a new method of communication to challenge existing norms. As an artist and as a woman artist I am always aiming to find ways to subvert the gender codes in the city I live. I know the attempt is also a collective one, therefore throughout the paper; I will list how women artists have developed their own strategies to challenge the dominant hegemony.

Through this paper, I would also like to see the possibilities to re-define the ancient belly dance form

\footnotetext{
1 Işıl Eğrikavuk studied Western literature at Boğaziçi University (Istanbul) then went to The School of The Art Institute of Chicago (SAIC) with Koç Foundation scholarship for her MFA in Performance Art. She taught art and media at Istanbul Bilgi University between 2009-2017. Since 2017, she lives in Berlin and teaches at Universität der Künste (UdK), Media and Communication Department. She is also expecting to complete her PhD in January 2021. Eğrikavuk is the co-winner of Turkey's first contemporary art prize, Full Art Prize in 2012. She is also the first recipient of SPOT Production Fund's artist grant. She has participated in numerous international exhibitions, residencies, and her work has been published in both local and international journals. She also wrote a weekly column, Güncel Sanat Kafası (High on Contemporary Art) at national newspaper Radikal for three years, where she commented on the intersection of daily news and contemporary art.
}

as a feminist practice and look for answers to overcome the general view that the dance is a way of entertainment that serves the male gaze. Could the dance indeed be re-defined as a feminist practice? Could it be owned by women who describe themselves as feminists? I will also try to answer these questions in the light of contemporary feminist artists who have opened the path for other women throughout history.

\section{Muted Group Theory}

Muted group theory, a theory originated from the researches of two cultural anthropologists, Edward and Shirley Ardener in the late 60's shows how language can be used as an instrumental tool for a group of people in society as well as focusing on how women have been muted throughout the history by the dominant gender, men. Ardeners both say the problem of muting exists for many groups in culture that are in asymmetrical relationships. Both of their interest and concern are about not just gender differences, but a range of other marginalizing differences as well. Yet, despite the fact that the muted group theory could be used to talk about any minority group that have been silenced throughout the history, Shirley Ardener especially focuses on the problem of dominance over women. Ardener questions whether "everyone in society has participated equally in the generation of ideas and discourse" (ARDENER, 2005, p. $51)$ and how this reflects on language, especially the language that are used to describe the representations, behaviors, codes and norms regarding women.

Ardener researches how women are referred even in academic studies and in popular forms of communication. She goes on further to exemplify how women are described as "wife", were parenthesized in researches, or as presented as equals to "horses and drinking" in academic studies or in major communication outlets. She quotes another academic Kirsten Hastrup and concludes that "while the male is generalized, the women is specified" (ARDENER, 2005, p. 52). Ardener also talks about how women throughout history have been muted in different segments of social life; 
Today I merely wish to emphasize that muting, by dominant groups through the control of dominant discourse, is refracted through and embedded in many different social spaces: in seating arrangements, prestige and power, religion and of course speech. (ARDENER, 2005, p. 51).

In like manner, Ardener goes further in asking whether groups in society have created different realities, or systems of values that do not get adequate recognition in the dominant representations of society. She especially focuses on how women were systematically othered on many different levels. Using Ardener's theory of muted groups as the base of my argument, but moving it onto a different geography and time, I would like to problematize how public space in Turkey has been used as a place of control over women's bodies, and thus how women are muted and made invisible by men. In order to prove my point and build up my argument, I will first refer to several scholars and their studies then bring their point of views into the field of visual arts. Finally, I will open up an argument to ask whether an artistic approach could become an alternative to challenge the existing norms of communication and among genders in today's Turkey.

However, I am aware that such contextualization could easily give way to an east-west duality in discussing gender and feminism. While talking about the third world women, by which I mean specifically Turkey, I specifically refrain from producing a single-type of representation of a third world women. Just like Chandra Talpade Mohanty beautifully puts it to her writing in her essay Under Western Eyes, I would also rather look at the case of Turkey from a transnational place. To say it in the words of Mohanty, "What I wish to analyze is specifically the production of the Third World Woman as a singular monolithic subject in some recent (Western) feminist texts" (MOHANTY, 2003, p. 333).

\section{Public space and its hierarchies}

Defining public space is already a problematized issue. In her book A World of Strangers, sociologist Lyn Lofland asks what it means for millions of strangers to exist side by side in a city. According to Lofland, behavior in public spaces entails observing the other. Lofland further argues that humans privatize public space through "locational transformations" (LOFLAND, 1973, p. 118). It is through these manufactured territories that humans privatize public space and learn how to act, dress and behave.

Yet, what are the boundaries of observing others? How do such locational transformations apply in places where public space is layered in a context of gender segregation? How do specific gender roles shape behavior in public spaces? What are the roles expected from men and women in public spaces? Do they open up limitations or opportunities for each gender? In a city like Istanbul, such questions become vital.

In his book, Behavior in Public Spaces, sociologist Erving Goffman starts by saying that in diagnosing mental disorder, psychiatrists typically cite aspects of the patient's behavior that are 'inappropriate in the situation'. According to Goffman interaction between two individuals occur through first 'unfocused interaction' when one gleans information about another person present by glancing at him (GOFFMAN, 1963, p. 24). Goffman introduces a second step, a focused interaction when persons gather close together and openly cooperate to sustain a single focus of attention typically by taking turns at talking. Under such a category, he goes on to define 'civil inattention' when one person stares at the others while at the next moment withdrawing one's attention from him so as to express that he does not constitute a target of special curiosity (GOFFMAN, 1963, p. 84).

It is this civil inattention that seems healthy in a society where one looks at the other in curiosity. Yet, there is a fine line where the 'civil' becomes 'uncivil' and crosses the border of curiosity by turning it into staring and violation of the other. Scholars, such as Carol Gardner take Goffman's points further, to the point that it is considered as harassment. Carol Gardner inverts this category and introduces the term, 'uncivil attention' which involves forms of public harassment and abuse (GARDNER, 1995, p. 112). 
What interests me is the uncivil attention in Gardner's terms and how this uncivil act of staring into one's body, usually from male to female, becomes normal in public space. This act of staring is so common in Istanbul to such a degree that while walking on the street in daytime, a woman can count numerous men looking at her body at the same time without moving their eyes. This form of uncivil attention from men to women is not just about the claiming of public space, but also claiming women's bodies as part of the public space to be engaged in freely. To question the staring is no help to reverse the situation either. As in a recent incident, sitting with a friend of mine on the street pavement in Istanbul's Galata neighborhood, I realized my friend was being the object of such attention. I immediately asked the man if something was wrong. He came closer, directing his attention to me and said he wouldn't look if it was illegal to look, thus claiming his action as a legal right. What are the borders of such uncivil attention? To what degree are they considered 'just looking' and not 'acting'? Or are they another form of muting the other by threatening the other through the act of uncivil attention?

Feminist scholars such as Margaret Crouch claim that such interactions are forms of harassment (CROUCH, 2009, p. 137). I agree that uncivil attention is not only muting but also harassing one's rights to act freely and comfortably in public space. Crouch also adds that not only the use of public space but also street or transportation harassment is a major problem for women in many countries and it means controlling women's behavior in those spaces (CROUCH, 2009, p. 137).

In Turkey, street and transportation harassment is also a major issue for women, and the debate was fueled last year by the murdering of a 20-year-old university student by a minibus driver after she resisted rape in February 2015. Thousands of women were telling their harassment cases as an online campaign that started after the case with the hashtag \#sendeanlat (tellyourstory) (DAVIDSON, 2015). In a short period of time, women shared thousands of incidents that they face daily in schools, buses, work places and streets. In another recent incident, a bus assistant allegedly conducted a sexual assault on a female passenger while she was sleeping during her hours-long ride. According to media reports: The incident sparked the hashtag \#SapıkMetroKapatılsın, meaning shut down pervert Metro, to begin trending on Turkish social media, with some describing the incident and how it was handled as a hideous disgrace, embarrassing and despicable.

In this paper, the context of public space is mainly the street and its extensions, such as public transportation and these examples and thousands of other women's stories that follow them not only show women are muted in public space in Ardener's terms, but also how they are denigrated, violated, killed and made invisible by men. However, I am also interested in how we should categorize women as victims. While speaking about these cases of violations of one's bodily rights, I want to point that perhaps such uncivil attention also occurs within the academic writings as well in forms of categorizing women into certain stereotypes, and even from women to women, myself included. Chandra Talpade Mohanty's touches on this issue in her essay Under Western Eyes: Revisited, stating that although she doesn't come from the Western World, as an academic that is where she is located:

Interestingly enough, while I would have identified myself as both Western and Third World-in all my complexities-in the context of Under Western Eyes, in this new frame, I am clearly located within the One-Third World. Then again, now, as in my earlier writing, I straddle both categories. I am of the Two-Thirds World in the One-Third World. I am clearly a part of the social minority now, with all its privileges; however, my political choices, struggles, and vision for change place me alongside the Two-Thirds World. Thus, I am for the Two-Thirds World, but with the privileges of the One Third World. (MOHANTY, 2003, p. 507).

Indeed, while talking about repression and violation of women's human rights, how can we refrain from categories? How can we refrain from seeing fe- 
minism as a teaching from West to East? For Mohanty, the position is rather to create a transnational and anti-capitalist practice (MOHANTY, 2003, p. 509).

\section{- Artistic interventions and possibilities}

As an artist who comes from a journalistic background and also an academic, I am invested in how art could communicate in offering alternative solutions to existing socio-political problems. Having studied the canon of feminist artists, such as Suzanne Lacy, Valie Export and Guerilla Girls, I appreciated more and more how they have come up with different methods to draw connections between their art, body and their role in society, which in the long run contributed immensely to gender equality. In the year 2016 and in another geography; Turkey, I will search for other possibilities to create such spaces for women.

One of these women, Suzanne Lacy (b.1945) has been an extremely significant figure in dealing with issues of rape, poverty, racism and gender politics, which were extremely critical subjects regarding public space in the US in the 70's. In 1977, Lacy realized her renown work, Three Weeks in May, which focused on rape in Los Angeles. A collaboration with many other artists, the work incorporated political speeches, radio interviews, news releases, art performances and self-defense demonstrations in order to raise awareness on this issue. Lacy tracked the occurrence of rape during those 21 days on a large problems (See Figure 1). Through Lacy, the media also became interested in the problem and because there was an organized dialogue between the artists, civil organizations and community groups, their collective actions became more visible in public space.
Figure 1 - Performance In Mourning and in Rage. Event Memorial for Victims of Hillside Strangler Los Angeles, CA, 1977.

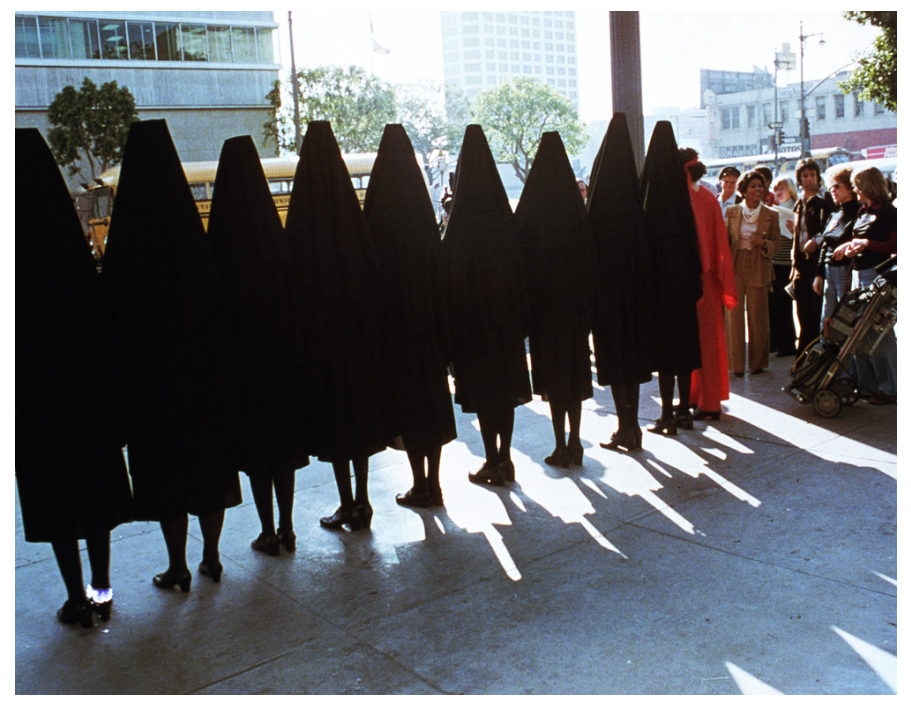

Source: Retrieved from https://www.againstviolence.art/ in-mourning-and-in-rage. 11 Jan. 2021.

Another influential woman artist, the Austrian Valie Export (b.1940) challenges the representations of womanhood and femininity in public space. Export's acclaimed work, Action Pants: Genital Panic in Public Space (1969) took place in Munich in an art cinema where experimental filmmakers were showing their work (see Figure 2). Export wore trousers from which a triangle had been removed at her genitalia, and waIked between the rows of seated viewers, exposing her vagina face-level to the sitting audience. This confrontation challenged the perceived cliché of women's historical representation in the cinema as well as in oil painting as passive objects that were denied agency. 
Figure 2 - Valie Export: Action Pants: Genital Panic in Public Space, 1969.

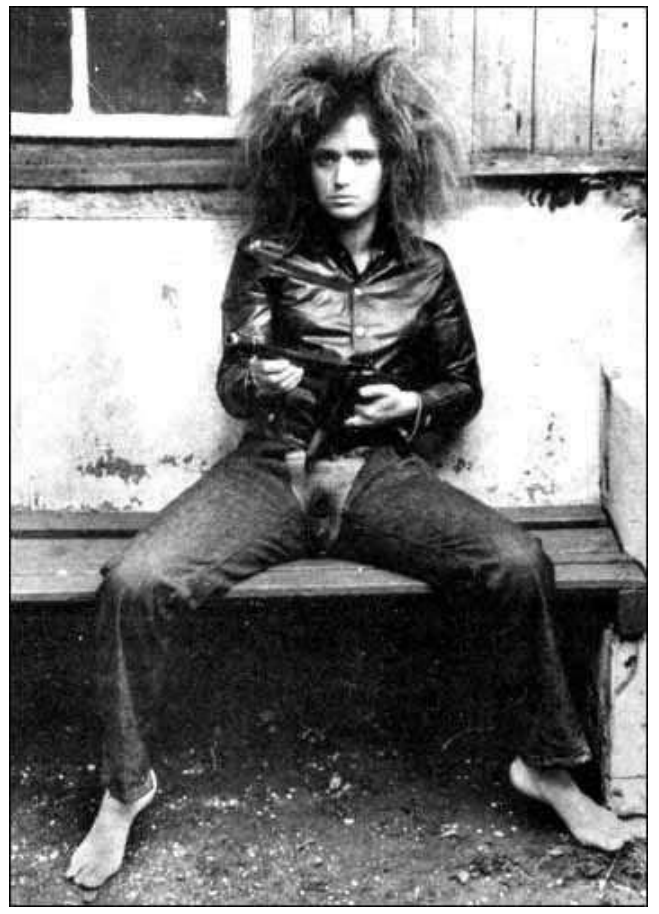

Source: Retrieved from https://hybridutterance.wordpress.com/2009/10/01/action-pants-1969-valie-export/. 11 Jan. 2021.

Looking from Ardener's point of view, it is quite obvious to see how women have been visually muted in art history as a sub-category of muted group theory. The representation of a naked, passive and inviting women image is extremely questionable and hard to generalize. Guerrilla Girls, whose work aim to expose sexual and racial discrimination in the art world, also point to the muting of women by reproducing well-known artworks with their own point of view. The poster below (Figure 3) Do women have to be naked to get into the Met. Museum? shows a naked woman who wears a gorilla mask. The poster below is based on the famous painting by Jean-Auguste-Dominique Ingres (Figure 4) and lists some facts: less than $5 \%$ of the artists in the Modern Art Sections are women, but $85 \%$ of the nudes are female.
Figure 3 - Guerilla Girls: Do Women Have To Be Naked To Get Into the Met. Museum? 1989.

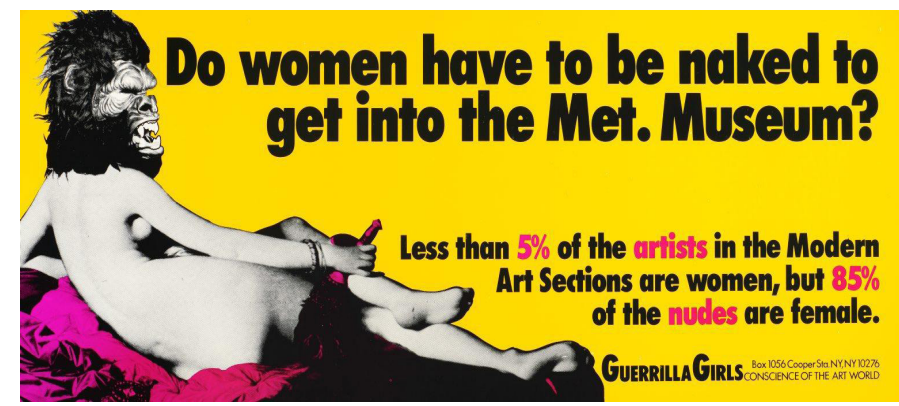

Source: Retrieved from https://www.artgallery.nsw.gov. au/collection /works/150.2014.24/. 11 Jan. 2021.

Figure 4 - Jean Auguste Dominique Ingres, La Grande Odalisque, 1814.

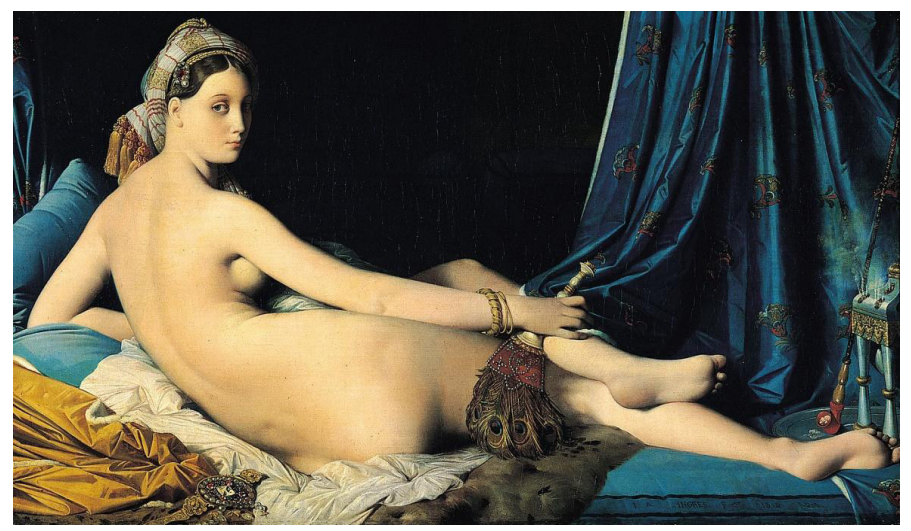

Source: Retrieved from

https://commons.wikimedia.org/wiki/

File:Jean_Auguste_Dominique_Ingres,_La_Grande_ Odalisque,_1814.jpg.11 Jan. 2021.

The poster was originally designed to be a billboard commissioned by the Public Art Fund in New York, but it was rejected on grounds of not being clear enough. The Guerrilla Girls then recounted: 'we then rented advertising space on NYC buses and ran it ourselves, until the bus company cancelled our lease, saying that the image... was too suggestive and that the figure appeared to have more than a fan in her hand.

Carrying the issue to Turkey, I would also like exemplify Turkish Artist Canan's (b.1970 and refuses to use her surname) billboard sign, Nihayet Içimdesin (Finally You Are in Me) (Figure 5). Canan's work, displayed on a billboard on top of an Internet café she and her husband owned in Istanbul at that time, was 
removed by the municipality of Kadıköy in the year of 2000, as there were complaints about the work. The artist, who was pregnant at the time, used the phrase Finally You Are in Me as a celebration to her long- wanted baby, yet her words were interpreted as a sexual act, as a woman who is longing for a male penetration. The dubious meaning of the work of course playful and is intentionally questions the double standards and the elasticity of the language. Yet, the removal of the work clearly shows how language is framed in the light of a one-sided male fantasy, placed in the mouth of a woman. When she clearly shows her excitement for something inside her, can it be something else other than a male sexual organ? The intervention on the work clearly shows a male fantasy since this wording is a cliché used in erotic films, yet also shows how scary it becomes to men once it is heard in public space. Both a fantasy and fear at the same time, it shows nothing but a fear of domination through women on language. Still the work succeeds in at least making the audience ask these questions.

Figure 5 - Canan, Finally You Are in Me, Billboard, 2000.

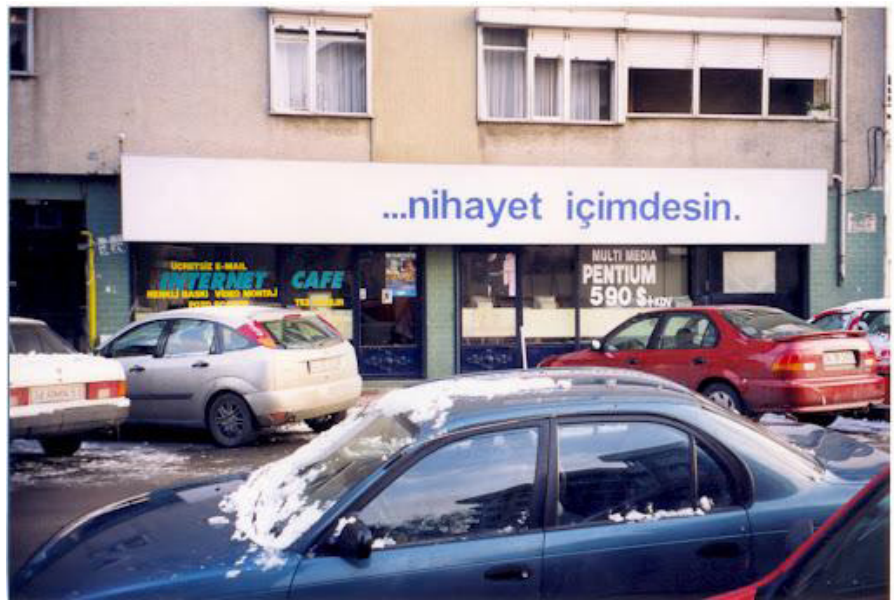

Source: Retrieved from http://www.siyah bant.org/bu-sanat-yapiti-cevreye-zararli. 11 Jan. 2021.

Finnaly, I will give an example from my own work, a video installation which was turned off by the Istanbul Municipality only three days after its opening. Located on top of the Marmara Pera Hotel, the video consisted a 30 second animation, which said Eve Finish Your Apple and ended with an apple slowly turning into a woman's face (Figure 6). As a response to single-God religions, in which the figure Eve is depicted as the cunning woman, who seduces Adam to eat the apple, I wanted to give the full responsibility to Eve, thus asking her to finish her apple and re-writing the narrative. I wanted to re-describe another possibility of defining Eve.

My work was shown in a public space, on top a $6 \times 9$ meter screen of Marmara Pera hotel and was supposed to stay there for a period of three months. However, it was shut three days after the opening by the municipality police, saying that it caused visual pollution and never was turned on again. I was never given an official explanation what defined visual pollution in a city, of which even the bridges are even decorated with neon lights at night.

Figure 6 - Işıl Eğrikavuk, Time To Sing a New Song, Video Installation, 2016.

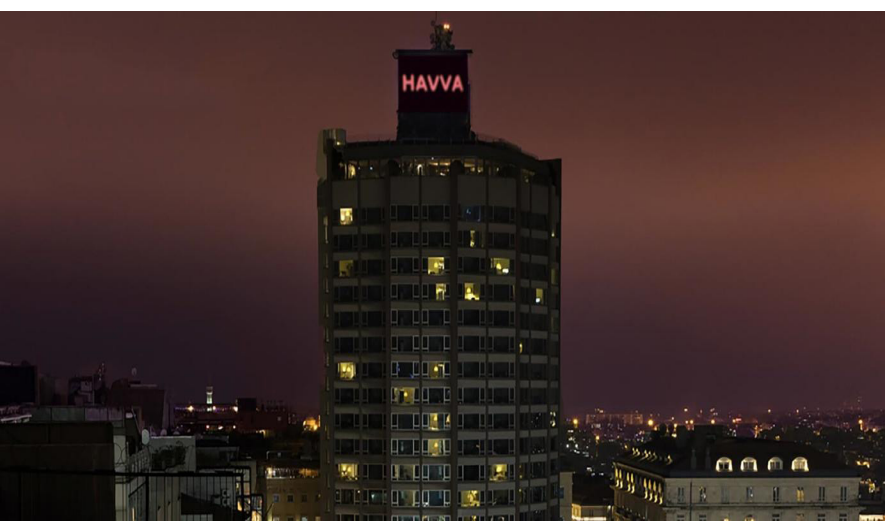

Source: Courtesy of the autor.

In the light of these examples, I would like to underline the capacity and power of art, which is an area mostly considered irrelevant to the existing sociological problems, and offer artistic thinking as a potential to challenge existing norms. I am invested in finding artistic strategies that may not necessarily bring a solution to the existing problem but could temporarily attempt reverse of such controlling modes. In the current framework of Istanbul, I want to ask whether an artistic strategy that involves dance, body and specifically the female body may connect women from different class and ages to 
their empowerment, and challenge these control mechanisms in public spaces created by men. As a starting point, I would like to offer to study belly dance as an artistic method towards empowerment.

\section{- Belly Dance, Oppression or Empowerment?}

What is the identity of a belly dancer? First of all, when we say 'a belly dancer', do we think of that person as a man or woman? In fact all sexes have bellies and all sexes, women, men and transgender people as well as intersex people can dance too. So why do we immediately associate the word with a half-naked woman, who shakes her body and dances in order not to entertain or express herself but to please the others? Why is belly dancing not considered self-expression but an entertainment service mostly for the male gaze? Why do we associate belly dancing, a practice mostly done by women, a lower form of entertainment or even a service industry where the naked body becomes the receiver of not only the gaze but also money?

Belly dance, Middle-Eastern Dance or Oriental dance, whatever we may call the form has long been seen as a dance form that is exotic, sexual and susceptible for the male gaze. Multiplied throughout European paintings, travel writings and early Hollywood films as well as pop-icons of today, existing literatures on belly dance has long defined the form in a stereotypical way. The voluptuous, sensual belly-dancer body image calling for the gaze has been similar to what Said has described the constructed image of Middle East in his book Orientalism as "a place of romance, exotic beings, haunting memories and landscapes, remarkable experiences" (SAID, 1979, p. 1).
Figure 7 - Image of a belly Dancer.

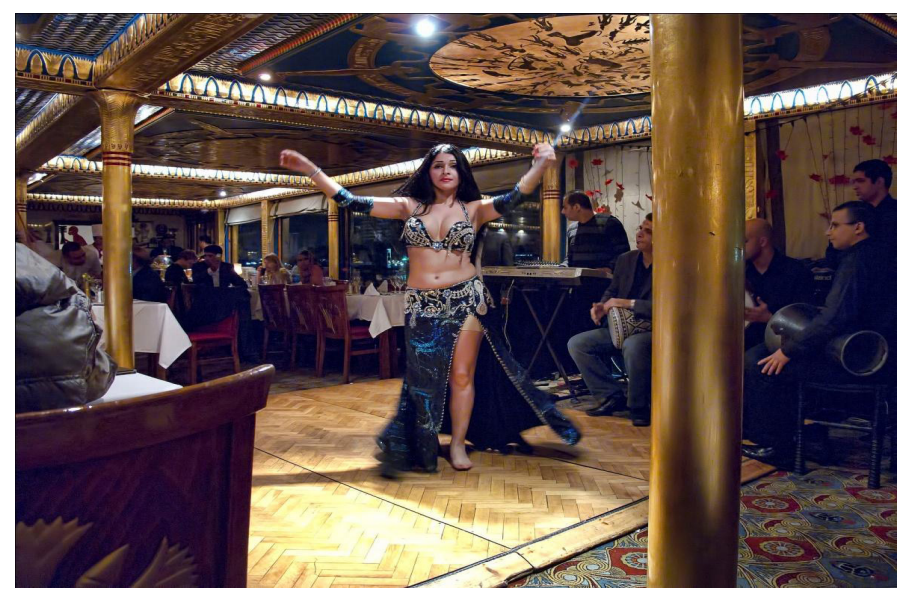

Source: Retrieved from

https://en.wikipedia.org/wiki/Belly_dance\#/media/ File:20111110_Egypt_0421_Cairo_dinner_cruise.jpg. 11 Jan. 2021.

Although there are many myths about the origins of the dance, some scholars suggest that traditionally this dance was usually performed in front of other women as part of family celebrations (NIEUWKERK, 1995, p. 12). Others also refer the dance as an ancient worship ceremony, claiming that the female dance was actually related to celebrating sexuality and fertility (BUONAVENTURA, 1998, p. 34-35). Such an approach to the dance was also appropriated by some feminist dancers in the US, especially in the 1970's, who attempted to reclaim this dance form as a strategy to reconnect their body with femininity. Backed by the emergence of 'goddess feminism' in the US in the 70's, some also drew connections between belly dance, ancient goddess and fertility cultures. These feminist advocates of belly dance worked to redefine the sexualized stereotypes previously associated with the dance and instead promoted belly dance as a celebration and awakening of feminine creative forces (KEFT-KENNEDY, 2005, p. 50). Backed by a popularized version of a fitness industry, by 1979 the American Broadcast Company reported that more than one million women in the United States alone were taking belly-dancing classes (SELLERS-YOUNG, 1992, p. 143). 
Despite the fact that the dance originates from India, North Africa and the Middle East, such a redefinition attempt doesn't seem to not take place in those geographies however. Instead, today the dance remains to be seen under the frame of its Orientalist definitions, where a half-naked woman dances to please the audience gaze. Moreover there has been a limited number of scholarly works on the dance. According to Keft-Kennedy, while an academic interest in belly dance has been slowly emerging since the late 70's, this research has tended to be either overly concerned with the historicizing of the dance, or is fixed with issues of authenticity and classification (KEFT-KENNEDY, 2005, p. 24). I would add that such scholarly interest, whatever its focus may be, is also mainly is from the West. The existing academic literature on belly dance in Turkey lies thin on the ground. Therefore a critical investigation into the ways in which such dance has been categorized will highlight an area that has long been undervalued.

The devaluing of belly dance in the Middle East to me seems like a major example of repressing women's expression of sexuality, energy, and fertility. In this case, the muting does not take place on the level of language, but on the body. Here the muting process functions through de-contextualization of the purpose of the dance. The expression of femininity through belly-dance is neither censored nor banned, yet it loses its original meaning and is made to be categorized as something low-cultured, lack of virtue and cheap. It no longer serves for the dancing women themselves, but deprived of its meaning, the dance becomes a sexual pleasure for the staring of men. Just like Ingres' Odalisque (Figure 4), the belly dancer represents not a real woman, but a sexualized being.

To me, such re-contextualization of the dance is not that different from the re-contextualization of public space. It is not democratic and devalues the presence of women. In that aspect, what will it take to reverse such fake contexts and put them back into their place?

\section{Muted Group Theory today and} possibilities of collectivity

In a recent paper titled Muted Group Theory and Communication: Asking Dangerous Questions, academic Cheris Kramarae takes the muted group theory further, and provides an answer to how the theory can be applied to today's conditions. According to Kramarae: In recent years there has been a lot of theorizing that deals explicitly with efforts to include the knowledge and creativities of many women as well as those of men; those theories are usually labeled feminist theories and are often marginalized, their explanatory potential still often limited to discussions in campus gender and women's studies classes (KRAMARAE, 1999, p. 55).

Kramarae's words show that although the feminist movement gained a major momentum in the 70's and 80's in the U.S., there is still a long way to go. Issues related to race, gender and identity are still major platforms of debate outside of the classrooms in everyday life. To move Kramarae's words into today's Istanbul, and given today's socio political climate, I am claiming that the muting of women is still a major issue in all segments of society, including critical issues such as inequality of rights, inequality of citizenship, street violence and sexual assault, oppression, harassment, and being muted.

My sole criticism towards Muted Group Theory applies here, where I claim that the Muted Group Theory shows the inequalities towards women, yet offers no alternative in how to correct or reclaim them. This I think leaves the theory on thin ground. It also helps to identify many of the asymmetrical relationships created through the muting of women and points them to our face, and leaves us with victimized positions, norms and studies. It is here that I think that art can intervene and act up as a catalyzer in correcting clichés, in re-placing them to act out in public space. It is only through art that one can imagine a space opening up for change.

Given this context, l'd like to ask: Could an ancient dance form create the space for women's empowerment and become an exemplary strate- 
gy to deal with oppressive gazing? Or does the dance itself fall into a category of oppression? In a context where gender roles are defined by hierarchies, what kind of possibilities does belly dance open up for women to achieve power?

As an artistic intervention, I am looking for ways to connect belly dance to female empowerment and see how such connection could open up a space for women to claim their position against discrimination. I am further asking what kind of artistic approach could carry the dance in the sphere of public space and subvert the roles between men and women, between the gazer and the dancer and between the oppressor and the oppressed.

I would like to imagine, rather than ask, whether collective dance sessions in public spaces of Istanbul, in buses, metros and parks, where women in daily clothing use movements from belly dance choreographies could be a form of protest and whether they can challenge the ways in which women have been represented in public space and in culture. I would also like to imagine that this form of collective dancing could re-voice our bodies and our identities in the way it was voiced once and start a new form of communication and existing in public space. If our voice is muted, perhaps it is our bodies that can give it its voice again. Issues regarding women's bodies, especially issues dealing with control and harassment of women's bodies are so timely that I believe such an investigation will not only serve artistic communities but larger platforms as well.

\section{Conclusion}

Through the trajectory of this paper, I have based my arguments on Shirley Ardener's Muted Group Theory by applying the theory to Istanbul 2016. The Muted Group Theory shows the asymmetrical relationships in a society, in which some groups are less voiced than others or completely shut down. I tried to pinpoint how this applies to today's society in Istanbul and not only through the muting of the language of and towards women, but also through the muting of women's bodies.
Muted Group Theory originates in anthropology. Yet, by connecting the discipline of communication to the discipline of visual arts, I am arguing not only that the two disciplines are unrelated, but also that these two areas have an immense potential to learn from each other and grow one another. The struggle for feminism is beyond disciplines of academic study. However, each discipline has its own methods and trajectory in fighting with patriarchy in everyday life or on a theoretical level. By bringing these fields together with art and dancing, I would like to open up another door, where the struggle becomes stronger in theory and more creative in activity.

Women have many abandoned practices, many abandoned words and many abandoned actions throughout history because these categories were banned, considered immoral or low by the patriarchy and its institutions. Identifying these categories and reclaiming them is a call to empowerment. It is only through reclaiming the ownership in language, in body, in thinking and in action and by collectively applying them into everyday that these abandoned practices can be claimed back. Belly dance is only one of the many abandoned or decontextualized practices, yet it shows how much women's bodies have been controlled, directed, and penetrated illegally. Throughout this paper, I moved from Muted Group Theory to public space, to artistic practices and interventions and feminist guerilla actions. By linking each discipline, I am seeing that there are and there will be new possibilities opening for change. To conclude with one quote from Ardener herself:

We are often like the dog turning in circles chasing a tail. Should the dog grasp it in his (or her) teeth he will find he discovers, not the 'other' but himself! Similarly, when facing our purportedly objective presentations of new facts, we are likely to find our own folk-images looking back to us. (ARDENER, 2005, p. 54). 


\section{References}

ARDENER, S. (2005). Muted Group Theory Excerpts. Women and Language, 22: na.

BUONAVENTURA, W. (1998). Serpent of the Nile: Women and Dance in the Arab World. New York: Interlink.

CROUCH, M. (2009). Sexual Harassment in Public Places. Social Philosophy Today, 25: 137-148.

DAVIDSON, H. (2015). Rape and murder of young woman sparks mass protest in Turkey. The Guardian. Retrieved from: http://www.theguardian.com/ world/2015/feb/17/turkish-woman-ozgecan-aslans-sparks-anti-violence-campaign-sendeanlat

GARDNER, C.B. (1995). Passing By: Gender and Public Harassment. Berkeley: University of California.

GOFFMAN, E. (1963). Behavior in Public Places. New York: Simon and Schuster.

KEFT-KENNEDY, V. (2005). Representing the Belly-dancing Body: Feminism, Orientalism, and the Grotesque. Wollongong: University of Wollongong.

KRAMARAE, C. (1999). A Revolutionary View of Communication; Cheris Kramarae's Theory of Muted Groups. Women and Language, 22:na.

LOFLAND, Lyn H. (1973). A World of Strangers; Order and Action in Urban Public Space. New York: Basic.

MOHANTY, Chandra Talpade. (2003) .Under western eyes revisited: Feminist solidarity through anticapitalist struggles. Signs: Journal of Women in culture and Society, 28,(2), pp. 499-53.

NIEUWKERK, K.V. (1995). A Trade like Any Other: Female Singers and Dancers in Egypt. Austin: University of Texas.
SAID, E.W. (1979). Orientalism. New York: Vintage.

SELLERS-YOUNG, B. (1992). Raks EI Sharki: Transculturation of a Folk Form. The Journal of Popular Culture, 26(2): 141-52.

Recebido: 23/11/2020

Aceito: $11 / 01 / 2021$

Aprovado para publicação: 01/04/2021

Este é um artigo de acesso aberto distribuído sob os termos de uma Licença Crea- tive Commons Atribuição 4.0 Internacional. Disponível em: <http://creativecommons.org/licenses/by/4.0>.

This is an open-access article distributed under the terms of the Creative Commons Attribution License 4.0 International. Available at: $<$ http://creativecommons.org/licenses/by/4.0>.

Ce texte en libre accès est placé sous licence Creative Commons Attribution 4.0 International. Disponible sur: <http://creativecommons.org/licenses/by/4.0>. 